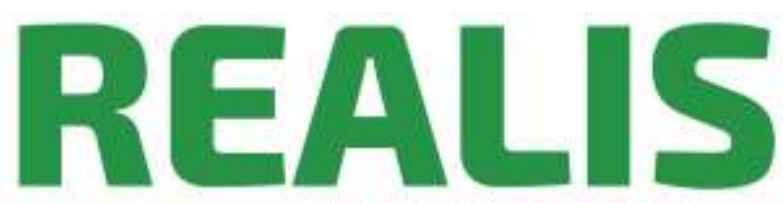

Revista de Estudos

AntiUtilitaristas e PosColoniais

\title{
IN 70 YEARS HOW DID THE NEW CHINA \\ ELIMINATE EXTREME POVERTY?1
}

Em 70 anos como a Nova China eliminou a pobreza extrema?

DUNFORD, Michael ${ }^{2}$

BING, $Q \mathbf{i}^{3}$

\begin{abstract}
China is noted for remarkable reductions in rural poverty and aims to eliminate it by 2020. Achieving this outcome requires identification of the remaining poor population and a strategy that effectively addresses the causes of their poverty. This article explores the ways in which China has converted itself from the poorest country in the world in 1949 to a country in which extreme poverty is on the verge of disappearance. It examines the roles of economic growth and a targeted combination of traditional development-oriented policy for poverty counties, villages and regions with wider minimum life guarantees and welfare services. The conclusions draw on a 2017 survey of 4,626 rural households and 13,689 individuals in 628 counties to point to some of the characteristics of the contemporary rural population.
\end{abstract}

Keywords: poverty alleviation; economic development; rural development; China.

Resumo: A China é conhecida por reduções notáveis na pobreza rural e tem como objetivo eliminá-la até 2020. Alcançar esse resultado requer a identificação da população pobre remanescente e uma estratégia que aborde efetivamente as causas de sua pobreza. Este artigo explora as maneiras pelas quais a China se converteu de país mais pobre do mundo em 1949 a um país em que a pobreza extrema está à beira do desaparecimento. Ele examina os papéis do crescimento econômico e uma combinação direcionada da política tradicional voltada para o desenvolvimento para condados, vilas e regiões pobres, com garantias mínimas de vida e serviços de bem-estar mais amplos. As conclusões se baseiam

\footnotetext{
1 Enviado em: 23 Out 2021. | Aceito em: 10 Nov 2021.

${ }^{2}$ Institute of Geographical Sciences and Natural Resources Research, Chinese Academy of Sciences, Beijing, China. https://orcid.org/0000-0002-0028-3130 m.f.dunford@sussex.ac.uk

${ }^{3}$ School of Marxism, Beijing Sports University and Chinese Studies Research Centre, Institute of Political Sciences, Chinese Academy of Social Sciences. cassqibing@foxmail.com.
} 
em uma pesquisa de 2017 de 4.626 famílias rurais e 13.689 indivíduos em 628 condados para apontar para algumas das características da população rural contemporânea.

Palavras-chave: redução da pobreza; desenvolvimento econômico; desenvolvimento rural; China.

Although the new socialist China established in 1949 is noted for remarkable reductions in poverty, poverty remains, predominantly in rural areas. In recent years, rural poverty has continued to decline rapidly, and the Chinese government was committed to ensuring that no Chinese household is beneath the national poverty line by 2020 . In spite of the unexpected arrival of the COVID-19 pandemic China was able to declare that it had achieved its target with all 832 poverty counties lifted out of poverty by the end of 2020 .

The decline in poverty since reform and opening up was largely due to sustained high rates of economic growth and rapid urbanization, but specific poverty alleviation measures also played an important role. At first these poverty alleviation measures largely involved area development policies for poor counties and poor villages. The impact of these measures was significant. As poverty declined, however, some of the problems that remained were increasingly difficult to resolve through development-oriented poverty alleviation and area development policy, in part as an increasing share of poor households were those for whom old age, illness, disability and an inability to work were causes of poverty and also as poor people lived outside of the main areas chosen for support.

To address these issues new measures targeted at individual households were introduced. As a result contemporary Chinese poverty targeting, considered as the avoidance of Type I errors of under-coverage (not helping people who need help) and Type II errors of assisting households that do not need help (Weiss, 2005) is relatively effective. And yet there remain concerns that households identified for support are not always the ones most in need, and that in a country in which family and kin relationships play an important role in welfare support and vast numbers of people work away from home as migrant workers (260 million at the time of the 2010 Census, 288 million in 2018) households that do not need personalized assistance are receiving it. 
To meet the first Chinese Communist Party (CPC) centenary target of ending poverty by 2020 and to coordinate poverty alleviation and minimum life guarantees a new targeted poverty alleviation programme to identify poor households was implemented in 2013-15.4 The aim of this article is to examine some of the main distinctive characteristics of people identified through these targeted instruments as remaining poor in rural China, the extent to which recent policy targeting has effectively identified poor households, the reasons for their poverty and the measures adopted to lift them out of poverty.

\section{Evolution of rural poverty and poverty alleviation policy}

In China poverty was and remains a predominantly rural problem. Although the line was low, in 1996 and 1998 just 2\% of the urban population had incomes beneath the corresponding national poverty line (World Bank, 2018). The comparable rural figures (using the 1978 rural poverty line) were 7.9 and 4.6\%. In 2010 the national rural poverty line was raised to 2,300 yuan $(\$ 348)$ per head at 2010 prices $(3,335 \mathrm{RMB}$ in 2018$)$ and the rural poverty headcount ratio jumped to $17.2 \%$ of the rural population (compared with $94.6 \%$ of the rural population beneath this 2010 poverty line in 1978). This figure has come down rapidly in recent years reaching $4.5 \%$ in 2016 and is intended to reach zero by 2020 (see.Figure 1).

\footnotetext{
${ }^{4}$ The Fifth Plenary of the $18^{\text {th }}$ CPC Central Committee held in October 2015 adopted two centenary goals for building socialism with Chinese characteristics: the construction of a moderately prosperous society by the centenary of the CPC in 2021 and making China a modern socialist country by the anniversary of the People's Republic of China in 2049.
} 
Figure 1 The poverty population in China, 1978-2019. Source: elaborated from National Bureau of Statistics

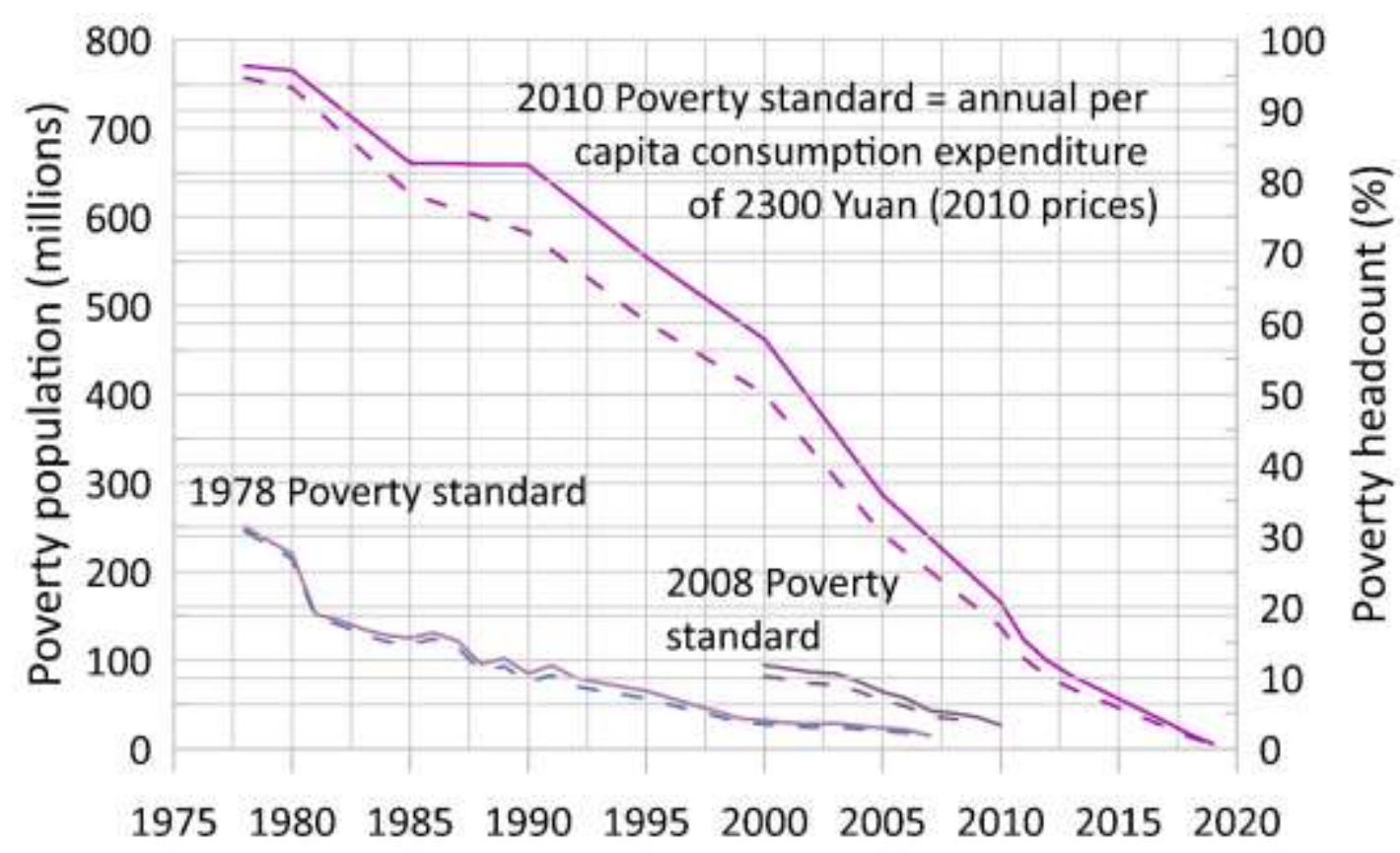

Poverty population (1978 standard) - - - Poverty headcount (1978 standard)

— Poverty population (2008 standard) - - - Poverty headcount (2008 standard)

— Poverty population (2010 standard) - - - Poverty headcount (2010 standard)

Comparative international data indicates just how exceptional the Chinese record is. At the World Bank $\$ 1.90$ per day poverty standard, the number of poor people in China declined from 877.8 million in 1981 to 25.2 million in 2013, accounting for an extraordinary $70.06 \%$ of the decline in world poverty (Table 1). Apart from on occasions in the late 1980s and very early 1990s, poverty declined continuously in China, whereas in other parts of the world (Eastern Europe and Central Asia in the 1990s, Latin America in the 1980s and 1990s and sub-Saharan Africa up to 2013, although slowing in the new millennium) sustained increases also occurred. 
Table 1 Number of poor people at $\$ 1.90$ a day (2011 PPP) (millions), 19812013. Source: elaborated from World Bank, Poverty and equity database

\begin{tabular}{|c|c|c|c|c|c|}
\hline & 1981 & 1990 & 1999 & 2013 & Change 19\{ \\
\hline East Asia \& Pacific & 1115.6 & 987.1 & 695.9 & 73.2 & 1042.4 \\
\hline China & 877.8 & 755.8 & 507.9 & 25.2 & 852.6 \\
\hline Europe \& Central Asia & .. & 13.3 & 36.8 & 7.7 & \\
\hline Latin America \& Caribbean & 47.0 & 62.5 & 69.3 & 27.8 & 19.2 \\
\hline Middle East \& North Africa & .. & 14.4 & 10.6 & 9.5 & \\
\hline South Asia & 504.8 & 503.1 & 476.8 & 257.3 & 247.5 \\
\hline Sub-Saharan Africa & 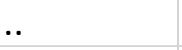 & 282.0 & 380.3 & 400.8 & \\
\hline World & 1903.5 & 1866.8 & 1731.9 & 782.7 & 1120.8 \\
\hline World without China & 1025.7 & 1111.0 & 1224.0 & 757.5 & 268.2 \\
\hline
\end{tabular}

As already mentioned, although sustained and rapid economic growth played a major role in reducing poverty, specific poverty alleviation measures were also important. In China's planned economy period, major advances in health and education saw internationally exceptional increases in life expectancy, population and literacy. In the early years of reform and opening-up from 1978 to 1985, poverty alleviation was largely a net result of institutional reform. Although reform resulted in significant reductions in rural health, education and welfare services, the replacement of the People's Commune System by the Household Contract Responsibility System, the relaxation of price controls for rural products and the rapid growth of Township and Village Enterprises providing nonagricultural employment saw farm and rural incomes increase quickly. In this phase the poor rural population (1978-2007 poverty standard) fell from 250 to 125 million (or from 30.7 to $14.8 \%$ of the rural population).

A new phase from 1986 to1993 was associated with a development-oriented poverty alleviation programme and large-scale planning financed by central state and supportive local government poverty relief funds. In 1985 most poor households (average annual income per capita of less than $200 \mathrm{RMB}$ ) lived in 18 extensive poor areas. Although not formally recognized until 2010, 2 of these areas were in Eastern China (32 counties), 7 in Central China (206 counties) and 9 in Western China (172 counties). In June 1986 in order to tackle the poverty problem in these areas, the State Council for the Economic 
Development of Poverty-stricken Areas (subsequently renamed several times and at present called the State Council Leading Group Office for Poverty Alleviation and Development (SCLGOP)) was established, an initial list of 331 key national poverty counties was drawn up and the development of characteristic local industries (to produce, process and commercialize higher value-added crop cultivation, aquaculture and animalraising) was the main policy instrument. In this phase the poor population fell from 125 to 80 million in 1992 (from 14.8 to 8.8\%).

From 1994 to 2001 the Eight Seven Poverty Alleviation Programme involved the identification of 592 nationally designated poor counties covering $72 \%$ of the rural poor population. Measures were designed to deal with the food and clothing problems of poor households and villages and were designed to lift 80 million people out of poverty in seven years.

As this stage came to an end greater mobility had increased the importance of investing in people and not just in the places they came from. More importantly, much of the remaining poverty was associated with the existence of households which, for one reason or another, included no one able to work. At the same time significant numbers of poor people resided and worked outside of the areas of most extensive poverty and were not always reached by area-development poverty alleviation policies. China already had a system of assistance for the most needy Five Guarantee Households (wǔ băo hù). The Five Guarantees date from a 1956 directive issued by the First National People's Congress entitled Exemplary Charter for Advanced Rural Cooperatives, requiring rural communes to provide food, clothing, fuel, education and burial expenses to farmers in extreme need, with no responsible kin and unable to support themselves. A new regulation dates from 2006 and covers senior citizens, disabled, children under 16 , and those unable to work and shifted the financial burden from a fund paid by farmers to government budgets. In 1998 a Medical Financial Assistance (MFA) scheme was implemented initially in 71 nationally designated poverty-stricken counties to reach the $5-10 \%$ of extremely poor people and was financed mainly by international development agencies. 
In 2001-2010 a fifth phase involved the implementation of the Outline for Development-oriented Poverty Alleviation for China's Rural Areas. The aims were to help the poor population in poor areas who had not yet solved basic clothing and food problems and to help the rest of the poor population increase household income. The measures adopted involved comprehensive village development (zhěng cūn tuījìn), labour training, micro-credit and poverty alleviation relocation. Comprehensive village development was designed to transform villages economically and make them more self-sufficient. A new targeting method was developed, identifying not just counties but villages and households. By the end of 2002592 key poverty reduction counties and 148,051 villages in ethnic minority areas in central and western China, old revolutionary areas (remote rural areas that supported the CPC during the Long March and the struggle with the Guomindang), border areas and areas with special difficulties were identified as eligible for national poverty financial assistance (along with all 73 counties in Tibet). Eastern Chinese poverty counties were removed from the national list and made the responsibility of provincial governments. Of the poverty villages, about $55.6 \%$ were within the key counties. Counties were identified by central government on the basis of income, social and geographical conditions, giving priority to remote, mountainous and minority areas. Villages were identified by counties using an integrated village poverty index reflecting living conditions, conditions of physical infrastructure and health and education conditions (Wang, 2005: 147). To support this policy the Ministry of Finance increased financial transfers for poverty alleviation, the Ministry of Finance and the National Development and Reform Commission (NDRC) established a work relief programme, the Agricultural Bank of China provided poverty alleviation credits, the NDRC incorporated poverty alleviation into the western development programme and a partnership (counterpart assistance) programme linked eastern and western areas (see Appendix 1). 
In a series of steps from 2002 to 2006 the government also phased out all agricultural taxes and fees, and significantly increased direct subsidies to agriculture ${ }^{5}$ to grapple with the inextricably interconnected sān nóng wèntí (the problems of rural people, rural society, and rural production) (Tiejun, 2001). From 1999 farmers whose arable land was reafforested (tuìgēng huánlín) under the sloping land conversion programme received fixed term annual compensation, enabling them to supplement this income from alternative work. From 2003 a New Rural Co-operative Medical Scheme was put into effect, as the earlier Rural Cooperative Medical Scheme had rapidly collapsed with the end of the Commune system. In 2003 a Rural Land Contracting Law of 29 August 2002 came into effect clarifying contracted rural land use rights and recognizing the right to transfer use rights for compensation. ${ }^{6}$

In same period the 2005 Fifth Plenary Session of the Sixteenth Central Committee of the CPC decided to 'construct a new socialist countryside' including a modernized agriculture and improved incomes and living conditions in rural settlements. Many high quality new settlements providing agricultural and other services for their hinterlands were established with rural households giving up their rural status for township residences. In other cases farmers gave up their land and their rural residential plot, received compensation and moved to a subsidized apartment in a larger urban settlement (W. Liu, Dunford, Song, \& Chen, 2016; Yep \& Forrest, 2016). In some areas however local governments opted for models of new rural construction that simply copied urban models in the countryside itself. In administrative villages composed of a series of village groups with clustered (yet sometimes hollowed-out) farmsteads(Y. Liu \& Long, 2015), expensive demolition and construction were carried out, and sometimes reluctant farmers were pressed to give up their farmsteads and move into multi-storey apartments (nóngmín

5 These subsidies included a food grain production subsidy (liángshi bǔtiē), a comprehensive subsidy for agricultural inputs (nóngzī zōnghé bǔtiē), a subsidy for improved seeds (liángzhǒng bǔtiē), a subsidy for the purchase of farm machinery (gòuzhì nóngjī bǔtiē) and various crop and region-specific subsidies (Li, 2014)

${ }^{6}$ An aim of these measures was to clarify farmers' rights. The central government was also anxious to prevent the not-infrequent violation of farmers' rights by officials, which was itself partly due to local government officials need to finance responsibilities for economic development, compulsory education and healthcare assigned to them by the central government without adequate resources. 
shàng lóu), destroying the rural landscape, rural scenery and cultural characteristics: as one official said, you cannot raise ducks on a balcony.

To address the problems of individual poor households in March 2007 the government extended the zuì dī shēnghuó băoxiăn (dī băo or minimum subsistence allowance) established in urban areas in the 1990s into a nationwide social assistance system. In contrast to the method of identifying poor areas, the identification of poor households involved a combination of means testing and participatory community-based targeting under the general management of a village committee. Communities took responsibility for setting specific eligibility criteria and determining and verifying eligibility. Households were supposed to be profiled in terms of per capita income, grain or food consumption, ability to work and development potential although special circumstances such as serious illness could also be considered, and the lists posted in the village. The main problems with this targeting method was that county and district governments set the di bao line in accordance with local living standards and local government finances and that decision-making remains open to corruption, nepotism and cronyism.

In 2011 the China Development-oriented Rural Poverty Alleviation Outline (20112020) designated 14 concentrated and connected very poor regions (quán guó jízhōng liánpiàn tèshū lèixíng pínkùn dìqū-concentrated special difficulty areas or CSDAs ) as the key battleground of poverty alleviation and development. The CSDAs comprise 680 counties, including 444 geological disaster prevention counties where frequent disasters result in a return to poverty of households that had escaped it. Of these counties, 440 were national poverty-stricken counties. The overall number of national poverty-stricken counties remained the same (592), although provincial governments changed the membership of their lists. Of these national poverty-stricken counties, 189 were deep poverty counties, and of this group 133 were minority counties. The 240 counties in the CSDAs not amongst the 592 counties were added to the full list of poverty counties to give 832 in all. The aim of the new programme was to guarantee the rural poor access to food, clothing, compulsory education, health and housing security, raise the rate of growth of 
income of poor rural households above the national average and ensure that public service provision moved closer to the national average. What was distinctive was that the fourteen large areas included important urban centres, opening the way to the development of wider regional development plans as a framework for more targeted interventions.

To establish an effective link between the poverty alleviation and the rural minimum living security system and contribute to the elimination of rural poverty, in 2013-14 a strategy of precise or targeted poverty alleviation (jīngzhǔn fúpín) emerged, while poverty alleviation was subsequently made one of the main objectives of the $13^{\text {th }}$ Five Year Plan (2016-20). Considered a major innovation, the targeted strategy involved accurate identification of poverty-stricken households and areas, the issue of poverty cards and establishment of computerized records, the careful mobilization of resources and design and implementation of plans (involving industrial support, micro-credit, infrastructure provision, improved housing, training and employment, relocation, educational and medical assistance and other measures) to lift households out of poverty. The standard was the 2013 national rural poverty alleviation standard of 2,736 yuan per capita taking account of housing, education and health. Farmers were required to apply, and their applications were to be subject to democratic appraisal and public audit involving village congresses, villagers' committees, village task forces and township governments. The audit was designed to identify the situation of poor households and the causes of poverty. Households were paired with government officials and Communist Party members required to work with local institutions to identify measures and resources and develop and implement individualized assistance plans. The results of the assistance and the performance officials were to be assessed with the assessments playing a part in the Cadre Responsibility System (gànbù zérèn zhì). And the information was to be entered into a networked national poverty alleviation information system and updated.

At the same time precise criteria and procedures were formulated for the exit of poverty counties, of which there were 832 at the end of 2016, along with 129,000 poverty stricken villages. A county can be removed from the list if less than $2 \%$ (3\% in Western 
China) of its population lies below the poverty line. In 2017, 28 counties cast off poverty, shortening the list for the first time in 30 years.

Another aim of the CPC and government was to 'strengthen social supervision over the performance of poverty alleviation work, carry out surveys of people's satisfaction with poverty alleviation in poverty-stricken areas, and establish a third-party evaluation mechanisms for the implementation ... and effectiveness of poverty alleviation' (CPC and State Council, 2015, zhōnggòng zhōngyāng guówùyuàn guānyú dăyíng tuōpín gōngjiānzhàn de juédìng [Decision of the Communist Party of China and the State Council on winning the fight against poverty], 29th November 2015). http://www.gov.cn/xinwen/201512/07/content 5020963.htm.

\section{Conclusions (and some evidence)}

China has made remarkable progress in reducing rural poverty, and, while sustained rapid growth was an important contributory factor, the implementation of a series of poverty alleviation policies have interacted with and contributed to national and regional economic growth and reinforced poverty reduction. After first targeting poverty counties, attention was subsequently also paid to poverty villages, and more recently to larger CSDAs. Increasingly, however, attention has had to be paid not just to developmentoriented poverty alleviation but also to minimum life guarantees and public services in rural areas throughout China, as the rural poverty that remains is often associated with old age, ill health and an inability to work and is found outside of the areas targeted by area development policies.

Figure 3 Age, gender and location of the sample population. Source: elaborated from 2017 household survey data. 


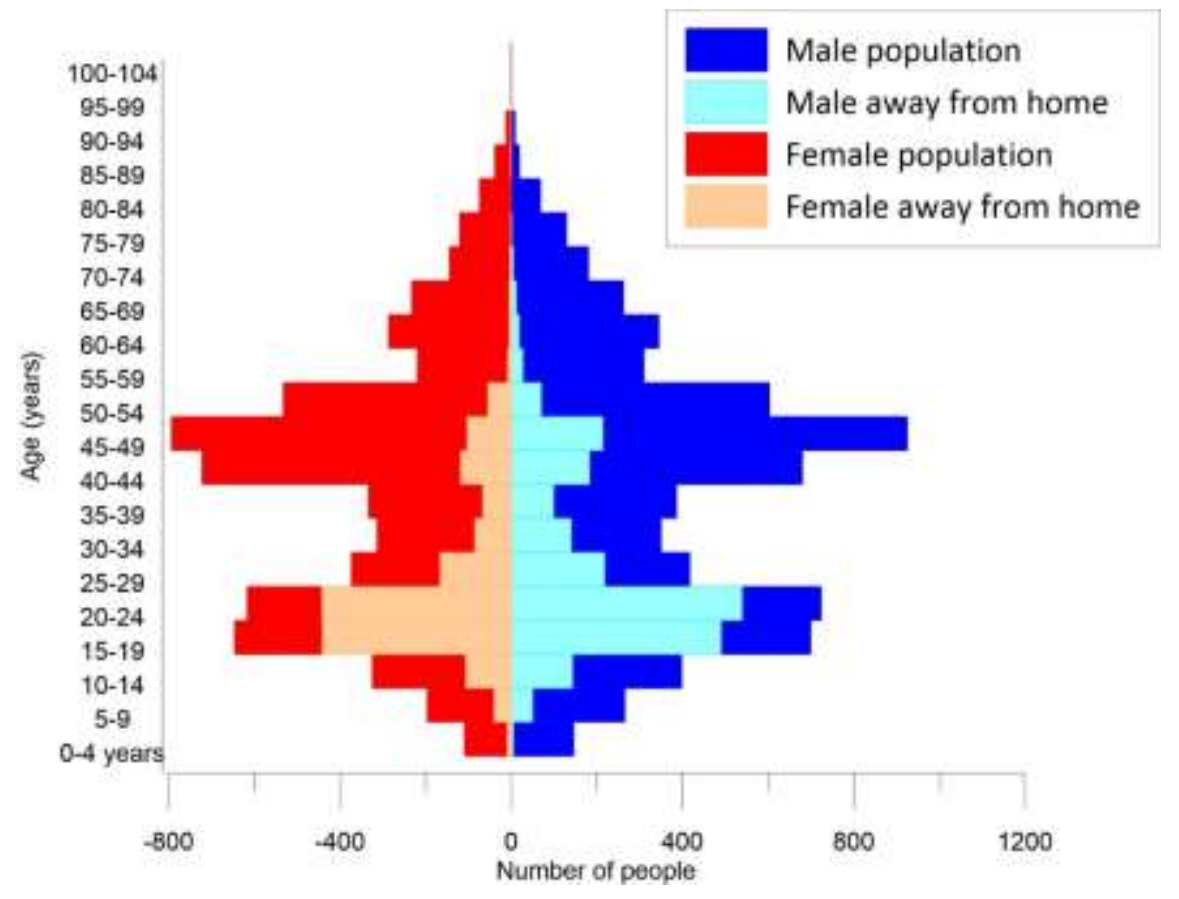

A large survey of 628 counties, 4,626households, and13,689 people (, see Figure 3Dunford, Gao, \& Li, 2019) shows that a number of factors play an important role in determining household income and the classification of households and counties. Off-farm work, the amount of agricultural land, household size, educational attainment all increase income and reduce poverty, whereas age, illness, debt and minority status all contribute sometimes indirectly to them. The results also indicate the effectiveness of some measures designed to address these drivers, and, in particular, the success of measures to ensure that all Chinese spend nine years in compulsory education.

Figure 4 Average household cash income by source (NPH=not poverty household, NPC=not poverty county, PH=poverty household, PC=poverty county). Source: 2017 household survey. 


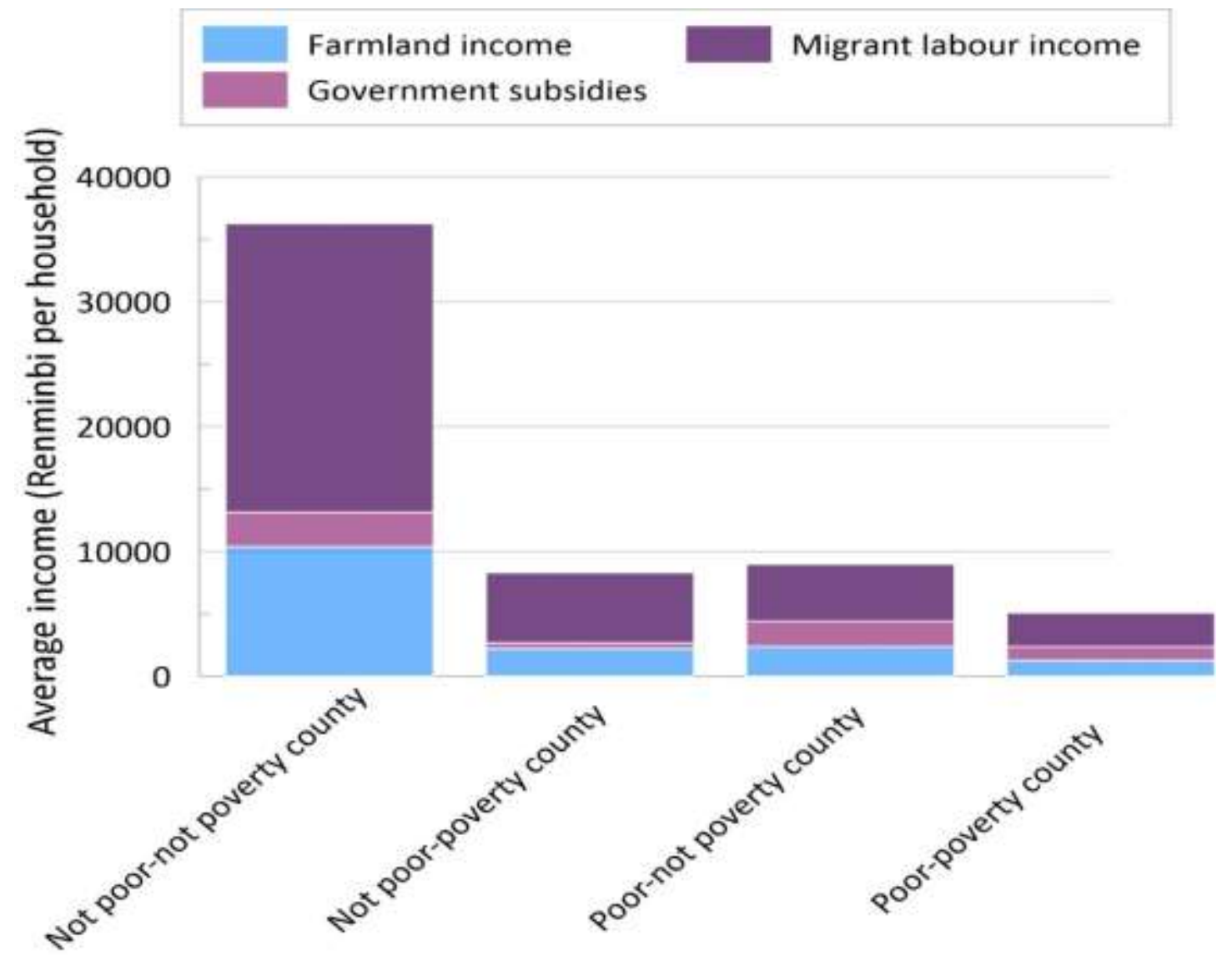

The survey confirms the importance for rural household income of the fact that around 288 million Chinese people are members of a 'floating' population. In many cases one or more registered members of rural-urban households live and work for different shares of each year in urban areas (see Figure 4). Outmigration of predominantly younger adults interacts with increased longevity and restrictions on family size (which were less restrictive and strict in rural and minority areas) to contribute to an ageing of the rural population. Often the connections of migrants with their rural households remain close, with children sometimes remaining in the countryside, and remittances often comprising an important source of household income, as the results of this study suggest. At the same time, the physical absence of young people increases the productive and reproductive (child-care) burdens of elderly relatives.

Figure 5 Years of education by age of the sample population. Source: elaborated from 2017 household survey data. 

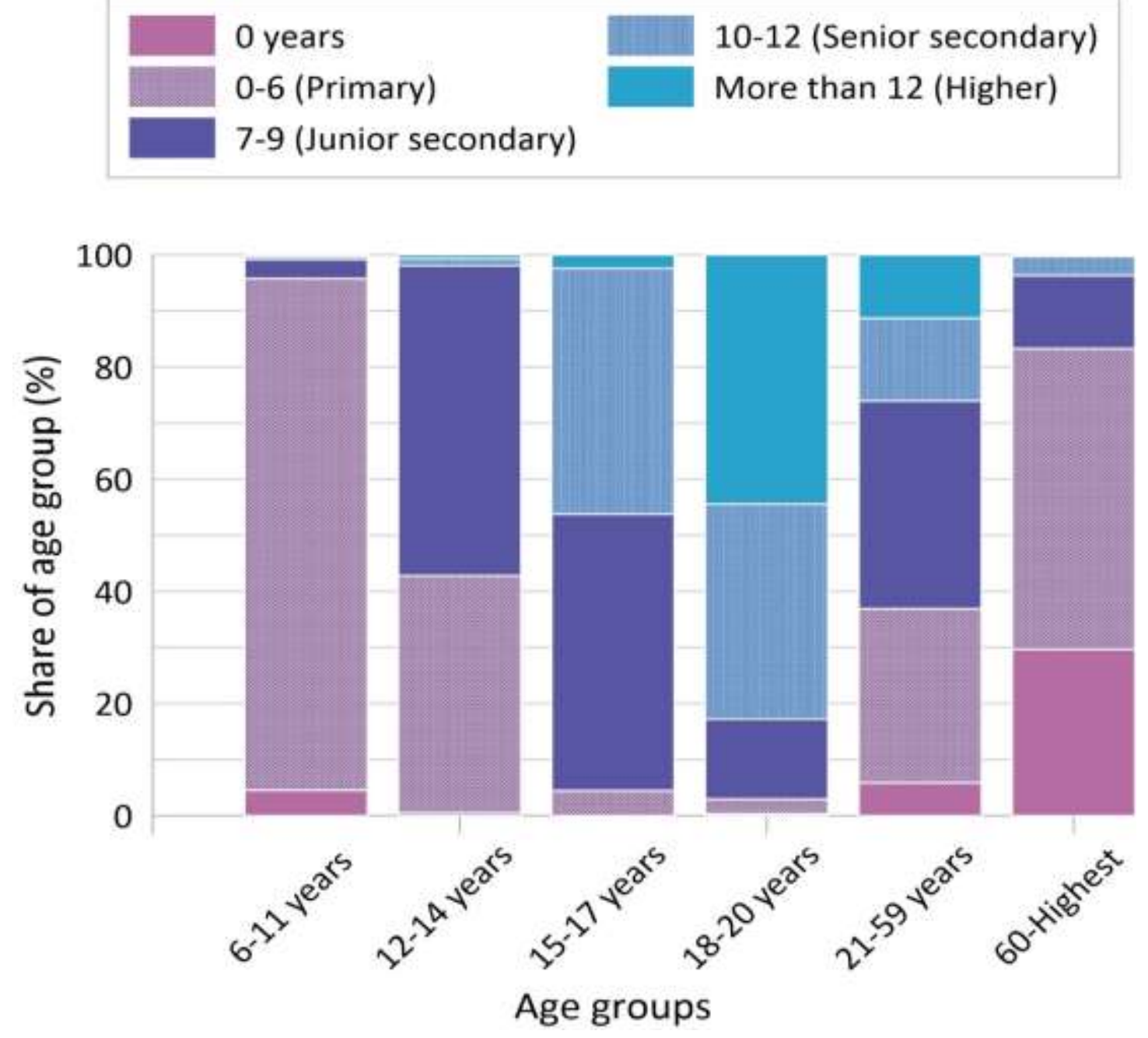

This situation is closely related to and yet also complicates the remaining problems of rural poverty. First, household income and poverty classifications are closely related with the share of the household who work outside of the agricultural sector and the share that is absent as well as with the importance of educational attainment (Figure 5) which enables access to higher quality employment. Second, low income and poverty status are closely related to illness and to the share of elderly people. These difficulties are addressed through rapidly widening minimum life guarantee, health and old-age insurance schemes. In many cases poverty households live outside of designated poverty counties. Third, the fact that it is not clear to what extent rural migrant earnings are remitted makes the identification of poverty households complex. China has tried to resolve these identification problems through public participation and careful evaluation of the situation of each household, but it remains far from easy. 
The survey shows that the households and localities targeted by poverty-alleviation measures are, in terms of the self-reported information identified fairly effectively: in particular the groups that emerge out of the poverty targeting exercises are clearly sharply differentiated from the rest. Moreover, in the survey just 9.4\% of respondents thought that officially identified poverty households were mainly not the poorest ( $25.1 \%$ did not know).

Finally, the results indicate the importance of a two-sided approach to poverty alleviation. To deal with some of the remaining problems, it is clear that measures to support households unable to work are increasingly important, as are measures to improve access to health and education services which low income groups can ill afford. At the same time, in terms of average and median household income very large differences between poverty and non-poverty counties remain, while poverty still particularly adversely affects certain minority groups concentrated in the most remote areas with few resources and subject to frequent natural disasters. The integration of these areas into much wider regional development strategies for the CSDAs may enable mechanisms that have operated nationally in the past to operate at a regional scale in these areas providing improved and more highly rewarded employment and economic opportunities.

\section{References}

DUNFORD, M., GAO, B., \& LI, W. (2019). Who, where and why? Characterizing China's rural population and residual rural poverty. Area Development and Policy, 1-30. doi:10.1080/23792949.2019.1571425

LI, S. (2014). Poverty Reduction and Effects of Pro-poor Policies in Rural China. China \& World Economy, 22(2), 22-41. doi:10.1111/j.1749-124X.2014.12060.x

LIU, W., DUNFORD, M., SONG, Z., \& CHEN, M. (2016). Urban-rural integration drives regional economic growth in Chongqing, Western China. Area Development and Policy, 1(1), 132-154. doi:10.1080/23792949.2016.1151758 
LIU, Y., \& LONG, H. (2015). Transformation of rural China. In M. L. Dunford, Weidong (Ed.), The geographical transformation of China (pp. 88-110). London and New York: Routledge.

TIEJUN, W. (2001). Centenary reflections on the 'three dimensional problem' of rural China. Inter-Asia Cultural Studies, 2(2), 287-295. doi:10.1080/14649370120068586

WANG, S. (2005). Poverty targeting in the People's Republic of China. In Poverty targeting in Asia (pp. 136-185). Tokyo, Cheltenham (UK) and Northamption, MA (USA): Asian Development Bank Institute and Edward Elgar.

WEISS, J. (2005). Experiences with poverty targeting in Asia: an overview. In J. Weiss (Ed.), Poverty targeting in Asia (pp. 1-33). Cheltenham and Nothampton, MA.: Edward Elgar.

YEP, R., \& FORREST, R. (2016). Elevating the peasants into high-rise apartments: The land bill system in Chongqing as a solution for land conflicts in China? Journal of Rural Studies, 47, 474-484. doi:10.1016/j.jrurstud.2016.07.017 